\title{
Między wzorcem a rzeczywistością. Socjalizacja żydowskich dziewcząt w polskojęzycznych pisemkach dla dzieci 1925-1930
}

\author{
BETWEEN THE IDEAL MODEL AND REALITY: SOCIALIZATION OF JEWISH GIRLS \\ IN POLISH-LANGUAGE MAGAZINES FOR CHILDREN, 1925-1930
}

\begin{abstract}
This article compares the patterns passed on in the years 1925-1930 by children's magazines to Jewish girls with how they actually assessed themselves, what they considered important, what plans they had for the future. The author conducted an analysis of three Polish-language magazines for children: Chwilka, Dzienniczek, and Mały Przeglad. The first two contained texts by adult authors who showed children the accepted models of behavior and expectations from them. However, the patterns were divergent. On the one hand, girls were taught to be obedient and polite, and on the other hand as future inhabitants of Palestine they were supposed to be rebellious and courageous. These contrasting demands could not be reconciled. In Mały Przeglad, which published texts written by children, we find information about how young girls assessed themselves and what they were striving for. It seems that the contradictory requirements that could not be met led to far-reaching emancipation, perception of discrimination against women, and the choice of one's own way of life.
\end{abstract}

Keywords: Jews, Zionism, socialization, girls.

Słowa kluczowe: Żydzi, syjonizm, socjalizacja, dziewczęta.

\section{Wstęp}

Prace, które analizują pozycję i rolę kobiet, także w społeczeństwie żydowskim, skupiają się niemal zawsze na losach dorosłych kobiet, a nie dzieci. Na przykład, bardzo interesujący artykuł Aliny Całej pokazuje sytuację 
kobiet w rodzinach żydowskich, złożoność ich ról, przemiany, jakie zachodziły w dwudziestoleciu, ale oparty jest na autobiografiach nieco starszych osób, które nadesłały swoje prace na konkurs YIVO $^{1}$. Najmłodsi autorzy mieli już szesnaście-siedemnaście lat² .

Powody tej luki w badaniach są w zasadzie dwa. Przede wszystkim zachowało się niewiele źródeł. Dzieci bowiem rzadko pozostawiają po sobie pamiętniki, listy, wspomnienia spisywane jeszcze w bardzo młodym wieku, a nie przefiltrowane przez dorosłe doświadczenia. Jeśli nawet powstają jakieś pamiętniki czy dzienniki, to zazwyczaj nie są traktowane poważnie, oddawane do archiwów czy bibliotek. Druga sprawa to uznawanie dzieci raczej za przedmiot zabiegów pedagogicznych niż za osoby samodzielnie myślące i mające własny pogląd na wiele spraw, w tym także równouprawnienie.

Przy analizie procesu socjalizacji historycy zazwyczaj zajmują się jednostronnym przekazem - co dorosłe społeczeństwo ukazuje jako normy i wzorce najmłodszemu pokoleniu. W aspekcie historycznym można bowiem zbadać jedynie, jak konstruowane były zasady dotyczące wychowania, natomiast bardzo trudne - lub wręcz niemożliwe - jest sprawdzenie, jak wychowawcze wzorce funkcjonowały w realnym życiu danego pokolenia i jak były przez nie odbierane. Niełatwo zatem stwierdzić, jak dzieci odnoszą się do norm przekazywanych przez dorosłych: czy je akceptują, czy krytykują - nie po latach, ale będąc jeszcze pod ich wpływem wychowawczym.

W tym artykule wzorce przekazywane żydowskim dziewczynkom w latach 1925-1930 przez żydowskie czasopisma polskojęzyczne dla dzieci porównane zostaną z opiniami czytelniczek i czytelników: jak dzieci same się oceniały, co uważały za ważne, jakie plany miały na przyszłość. Istnieją wyjątkowe źródła, które pozwalają spojrzeć na sprawę z obu stron - zarówno dorosłych, jak i dzieci. W latach 1925-1939 ukazywały się trzy pisma dla żydowskich dzieci skierowane do tej samej grupy

${ }^{1}$ Ukazały się dwa zbiory autobiografii: Awakening Lives: Autobiographies of Jewish Youth in Poland before the Holocaust, red. Jeffrey Shandler, New Haven-London 2002, oraz - w języku polskim - Ostatnie pokolenie. Autobiografie polskiej mtodzieży żydowskiej okresu międzywojennego ze zbiorów YIVO Institute for Jewish Research w Nowym Jorku, red., wstęp i przypisy Alina Cała, Warszawa 2003. Analizą tych autobiografii zajmował się Kamil Kijek - zob. Kamil Kijek, Dzieci modernizmu. Świadomość, kultura i socjalizacja polityczna młodzieży żydowskiej w II Rzeczypospolitej, Wrocław 2017.

2 Alina Cała, Kobiety wobec tradycyjnych norm życia rodzinnego $w$ społecznościach żydowskich w Polsce międzywojennej, [w:] Kobieta i kultura życia codziennego, wiek XIX i XX, red. Andrzej Szwarc, Anna Żarnowska, Warszawa 1997, s. 90. 
odbiorców - polskojęzycznych (albo przynajmniej dobrze znających język polski), wywodzących się z rodzin o sympatiach syjonistycznych ${ }^{3}$. To dodatki do trzech dzienników: warszawskiego „Naszego Przeglądu”, lwowskiej „Chwili” i krakowskiego „Nowego Dziennika”. Pierwsza na pomysł wydawania dodatku dla dzieci swoich czytelników wpadła lwowska „Chwila”4 w 1925 r. Początkowo redaktorką „Chwilki dla Dzieci i Młodzieży” była Runa Reitmanowa, lwowska działaczka społeczna zajmująca się dziećmi. Następnie najpopularniejszy polskojęzyczny dziennik żydowski „Nasz Przegląd” zaprosił do współpracy Janusza Korczaka i tak powstało w 1926 r. najsłynniejsze z dziecięcych pisemek: „Mały Przegląd”5. Jako ostatni dołączył krakowski „Nowy Dziennik”, który od 1926 r. wydawał co dwa tygodnie dodatek „Dzienniczek dla Dzieci i Młodzieży”, również pod redakcją Runy Reitmanowej.

„Chwilka” i „Dzienniczek dla Dzieci i Młodzieży” miały charakter typowych pisemek dla najmłodszych. Publikowano w nich teksty dorosłych autorów - wierszyki, opowiadania, powiastki z morałem, odpowiadano na listy czytelników. Owszem, drukowano czasem teksty czytelników, ale nigdy nie stanowiły one głównej zawartości pisma. Jako że obie gazetki w omawianym okresie miały tę samą redaktorkę naczelną, Runę Reitmanową, trudno się dziwić, że idea wychowawcza była zasadniczo identyczna. Ambicją redakcji było wychowywanie czytelników obojga płci na dobrych Żydów i wzorowych syjonistów, przy czym jednocześnie prezentowano dosyć tradycyjną wizję wychowawczą, w której królowały grzeczne dzieci, odgórne i arbitralne rady oraz pouczenia dorosłych, a także typowy „dziecinny" język, z wieloma zdrobnieniami.

Żadne z tych czasopism nie zajmowało się szczególnie ani problematyką płci, ani rolą dziewcząt i kobiet w społeczeństwie. Nie było dla nich zasadniczą sprawą to, jak powinny się zachowywać żydowskie dziewczynki, jak same się postrzegały, jakie miały ambicje, czy czuły się dyskryminowane, jak były oceniane przez chłopców. Część tych tematów poruszano marginesowo, czasem w opowiadaniach dotyczących innych problemów. Niemniej na podstawie publikowanych tekstów zupełnie dobrze da się odtworzyć rolę - albo raczej role - jaką przypisywano dziewczętom żydowskim.

${ }^{3}$ Oczywiście czasopisma te czytane były także przez osoby o innych poglądach politycznych, a nawet przez polskich czytelników. Jednak kierowane były do konkretnej grupy odbiorców i przekazywały idee syjonistyczne.

4 „Chwila” - syjonistyczny dziennik wydawany we Lwowie w latach 1919-1939.

${ }_{5}$ Zob. Anna Landau-Czajka, Wielki „Mały Przegląd”. Społeczeństwo i życie codzienne w II Rzeczypospolitej w oczach korespondentów „Małego Przegląu”, Warszawa 2018. 
Istniał jednak „Mały Przegląd”, który można wykorzystać do zbadania realnych postaw najmłodszych Żydówek w Polsce i porównania z tym, co usiłowano im narzucić. Ukazało się trzynaście roczników „Małego Przeglądu" (1926-1939). To jedyne w swoim rodzaju pismo -tworzone przez dzieci, które były zarówno autorami listów i tekstów tam zamieszczanych, jak i reportaży czy esejów. Także redaktorami (poza redaktorem naczelnym) były dzieci. Oprócz tego pisma taki charakter miały w tym czasie wyłącznie szkolne i w pewnym zakresie organizacyjne pisemka ${ }^{6}$, ale były one nadzorowane przez nauczycieli i wychowawców, trudno więc mówić o swobodnym przekazie.

Normy przekazywane dziewczynkom były paradoksalnie najmniej i zarazem najbardziej widoczne właśnie na łamach „Małego Przeglądu”. Poza pierwszymi numerami (i numerami wakacyjnymi, w których głównie publikowano opowiadania żydowskich pisarzy) nie było w nim prawie tekstów pisanych przez osoby dorosłe. Brakowało więc rad, morałów, wskazówek kierowanych przez dorosłych do dzieci. Były tam jednak relacje samych dziewcząt, ich opinie na temat wymagań dorosłych, własnych ambicji, planów życiowych, relacji z chłopcami, polemiki na temat ról życiowych obu płci. Można oczywiście się zastanowić, czy i jak redakcja wpływała na dobór publikowanych opinii ${ }^{7}$. Nie zachowały się zbiory oryginalnych listów, nie sposób więc jednoznacznie stwierdzić, czy nie wybierano głównie tych tekstów, które odzwierciedlały postawy redaktorów. W przypadku kwestii politycznych takie sytuacje niewątpliwie się zdarzały i były sygnalizowane na łamach pisma, ale w wywoływanych dyskusjach stawiano raczej na prezentowanie różnorodnych poglądów8

Wszystkie omawiane czasopisma przeznaczone były zarówno dla chłopców, jak i dla dziewcząt, ale o ile w „Małym Przeglądzie” obie płcie reprezentowane były mniej więcej równo, o tyle w „Chwilce” i „Dzienniczku” w większości tekstów, które nie odnosiły się do obu płci, bohaterami bywali

${ }^{6} \mathrm{O}$ szkolnych pisemkach żydowskich dzieci zob.: Adina Bar-El, Jewish Children's Periodicals in Poland between the Two World Wars - in Three Languages, „Rocznik Historii Prasy Polskiej” 16 (2013), nr 1, s. 5-48.

Jedynym z problemów było skracanie listów, co czasem prowadziło do zniekształcenia treści. Dlatego też pomijałam te opinie, które zostały sprowadzone do jednozdaniowych wzmianek. Więcej zob. Landau-Czajka, Wielki „Mały Przegląd”...

${ }^{8}$ Joanna Papuzińska podkreślała, że w przeciwieństwie do cenzurowanych przez nauczycieli pisemek szkolnych Korczak nie ograniczał polemik i dyskusji, zob. Joanna Papuzińska, Prasa dziecięca okresu międzywojennego a „Mały Przeglad”, [w:] O „Małym Przegladzie” po latach. Materiaty ze spotkania korespondentów i czytelników, red. Anna Wernik, Warszawa 1989, s. 117-122. 
chłopcy, nawet przy pominięciu tych o bohaterach historycznych. Jeśli weźmie się pod uwagę odpowiedzi redakcji na listy czytelników, widać, że pisywali do „Chwilki” zarówno chłopcy, jak i dziewczęta, może nawet z przewagą tych drugich. W „Małym Przeglądzie” dziewczynki od początku wśród korespondentów przeważały, choć tylko nieznacznie ${ }^{9}$. Jedyne, co da się zauważyć, to w niektórych wypadkach dzielenie listów według płci autorów. Mamy więc na zakończenie trymestru lub roku szkolnego „Świadectwa chłopców” i „Świadectwa dziewczynek” czy „Dziewczynki o śniegu”, „Chłopcy o śniegu”10. To jednak wyjątki, a nie reguła, i w pierwszych latach istnienia „Małego Przeglądu” na jego łamach toczyły się liczne i bardzo ożywione dyskusje o roli obu płci i ich wzajemnych kontaktach.

Niniejszy artykuł obejmuje lata 1925-1930. Data początkowa to rok, w którym ukazał się pierwszy numer „Chwilki”. Jako datę końcową przyjęto rok 1930, mimo że wszystkie czasopisma ukazywały się znacznie dłużej. W tym przypadku istotna jest ewolucja „Małego Przeglądu”. W roku 1930 z kierowania redakcją zrezygnował Janusz Korczak. W kolejnych latach, gdy redaktorem naczelnym był Igor Newerly, pismo w coraz większym stopniu skierowane było do młodzieżowego czytelnika, zmieniła się też jego tematyka. Mniej miejsca zajmowała korespondencja od czytelników, a coraz więcej teksty stałych współpracowników pisma, którzy w większym stopniu reprezentowali „dorosłe” myślenie. Poza tym właśnie do 1930 r. jednym z najczęściej poruszanych tematów była pozycja kobiet w społeczeństwie, wzajemne odnoszenie się chłopców i dziewcząt, toczyła się dyskusja o stereotypach dotyczących obu płci, o tym, która z nich jest lepsza i więcej warta.

Pierwsza część artykułu dotyczy wzorców przekazywanych w „Chwilce” i „Dzienniczku”, druga - poglądów korespondentek „Małego Przeglądu”"11. Zamiarem jest ukazanie nie tylko rozbieżności między wzorcami, ale także zastanowienie się, jak dalece mogły one wpłynąć na emancypację żydowskich dziewczynek.

9 „Mamy zapisanych w 20 pocztach: 1142 nazwiska dziewczynek, 897 nazwisk chłopców. Dziewczynki zwyciężyły 245 punktów. Myśleliśmy, że będzie gorzej. Bo chłopcy wolą latać, niż pisać. Zresztą na pewno nie wiemy, bo prawie tysiąc jest takich, gdzie nie napisali, czy chłopiec, czy dziewczynka”. Dlaczego tak późno (statystyka), „Mały Przegląd” [dalej: „MP”] (25 marca 1927), nr 84, s. 8.

10 „MP” (21 lutego 1930), nr 52, s. 1-2.

11 W przypisach użyto następujących skrótów pełnych nazw czasopism: „Chwilka”, „Dzienniczek” i „MP”. 


\section{„Chwilka” i „Dzienniczek”. Idealna żydowska dziewczynka}

\section{Grzeczne i posłuszne}

W „Chwilce” i „Dzienniczku dla Dzieci i Młodzieży” przekaz kierowany do dziewcząt różnił się od tego, który przeznaczano dla chłopców. W odpowiedzi czytelniczce, która przyznawała, że zachowuje się niewłaściwie wobec starszych, radzono pracować nad sobą i starać się być posłuszną choć godzinę dziennie i pamiętać, że „Dzienniczek” martwiłby się, gdyby nie odniosła nad sobą zwycięstwa. W tym samym numerze do chłopca redakcja pisała: ,jesteś rezolutnym i dzielnym chłopcem"12. W opowiadaniach „Dzienniczka” i „Chwilki” chłopcy byli niezbyt grzeczni, dziewczynki raczej potulne, a z drugiej strony wrażliwe na krzywdę czy zmartwienie innych.

Dziewczynki, bohaterki opowiadań, miały być dobre i grzeczne, a jeśli takie nie były, to zachęcano je do zmiany postępowania. W opowiadaniu dla najmłodszych dzieci Ewusia:

Otworzyła oczka w łóżeczku pełnem promieni słonecznych - złożyła rączki i powiedziała sobie, chcę dzisiaj być dobrą. Prędko wyskoczyła z łóżeczka wesoła i rześka, ubierała się szybko, myjąc się nacierała dobrze swą białą skórę, by tak czystą była, jak jej mała współczująca duszyczka ${ }^{13}$.

Jednak bohaterce opowiadania niewiele przyszło z dobrych chęci. Obudzony braciszek ją obrażał, mama się gniewała, bo Ewusia zbiła kotka (ratując ptaszka, którego ten chciał zjeść), a w końcu brat, którego namawiała, aby poczęstował swoimi poziomkami gości, się rozzłościł. Wieczorem Anioł Stróż tłumaczył, że jeszcze nie umie być grzeczna i musi się nauczyć być dobra. Innymi słowy, dziewczynki pouczano, że nawet cudze złe uczynki są ich winą. W innym opowiadaniu obarczona obowiązkami domowymi Sarusia nie miała czasu nauczyć się lekcji. Koleżanka, która zwykle jej pomagała, tym razem odmówiła. Sarusia otrzymała zły stopień i była rozżalona. Ale gdy dostrzegła, jak koleżanka się przewróciła, po chwili wahania pospieszyła jej z pomocą:

Dobrze ci tak... myśli i już chce iść dalej... ale... serduszko Sarusi... nie pozwala nóżkom oddalić się... [...] Sarusia zbliża się do Hani... Pomaga jej wstać... zbiera jej książki i zeszyty [...] Przed domem Hania daje Sarusi mocnego całusa i mówi:

12 Odpowiedzi red. „Dzienniczka”, „Dzienniczek” (7 czerwca 1928), nr 151, s. 6.

${ }_{13}$ Dla grzecznych dzieci. Bajka o dziewczynce, która chciała być dobra, „Chwilka” (30 czerwca 1926), nr 2615, s. 7. 
- Tyś lepsza ode mnie Sarusiu... Nie gniewaj się... Codziennie będę do ciebie przychodzić i będziemy się razem uczyć..."14.

Innym istotnym elementem wychowania było posłuszeństwo wobec rodziców. Babcia opowiadała wnuczce bajkę z morałem, że należy zawsze być posłusznym mamie, niesłuchanie jej bowiem przynosi cierpienie i dziecku, i innym. Wzruszona dziewczynka deklaruje, że ona także pragnie być posłuszna, ale to trudne. Babcia zapewniła, że wystarczy chcieć. „Widzisz, tę samą bajkę opowiedziano raz innej małej, upartej dziewczynce, która myślała o niej tak długo, aż się poprawiła. Były to bowiem ostatnie słowa jej matki, która tej samej nocy umarła"15. Jak widać, posłuszeństwu nadano tu najwyższą możliwą rangę - było życiową wskazówką umierającej matki dla córki. W innym opowiadaniu chora dziewczynka kaprysiła, a budząc się, zauważyła zapłakaną matkę. Doszła więc do wniosku, że była dla niej niedobra - zjadła konfitury ze słoiczka, zaplamiła szal, stłukła coś przez nieuwagę, a w dodatku marudziła. „Mamusia musi płakać, skoro ma tak niedobrą córeczkę. [...] Nie płacz mamusiu. Nigdy już nie płacz... Będę już zawsze naprawdę grzeczna"16. I oczywiście, mimo choroby, dotrzymała słowa. Jak widać, córki powinny być posłuszne przede wszystkim dlatego, by nie sprawiać matkom problemów. To samo przesłanie można odnaleźć w „Dzienniczku” $\mathrm{i}$ to nie w opowiadaniu, ale wprost w odpowiedzi redakcji, która pouczała czytelniczkę, że jest już za duża, aby być „niegrzeczną” lepiej zastosować się do życzeń mamusi, „która na pewno wie, co jest dla ciebie dobre" 17 .

W rozlicznych bajkach dziewczynki bywały na ogół grzeczniejsze od chłopców, często stanowiły dla nich przykład, dokonując dobrych uczynków; były też zazwyczaj pogodzone z losem, jak na przykład umierająca dziewczynka w bajce Spadte liście ${ }^{18}$. Trzeba jednak zaznaczyć, że w opowiadaniach pojawiali się także chłopcy o złotych sercach.

Zajęcia zalecane dziewczynkom także były konwencjonalne. Ich zabawki należały do stereotypowych: lalka, miś, kuchenka z garnuszkami, mały serwis, pajac i klocki, z których jednak niczego się nie buduje, tylko układa

${ }^{14}$ Blanka Holleandrowa, Zemsta Sarusi, „Chwilka” (28 listopada 1929), nr 3836, s. 9.

5 X, Śnieżyczki, „Chwilka” (23 marca 1928), nr 3234, s. 8.

16 Blanka Holleandrowa, Łzy mamusi, „Chwilka” (14 lutego 1929), nr 3555, s. 9.

17 Odpowiedzi Redakcji, „Dzienniczek” (23 sierpnia 1928), nr 8, s. 5.

${ }_{18}$ Spadte liście, „Chwilka” (25 października 1928), nr 3445, s. 9. 
obrazki ${ }^{19}$. Mogły też podziwiać kwiatki albo zajmować się karmieniem głodnych ptaszków w zimie ${ }^{20}$.

Dziewczynki powinny dobrze się znać na pracach domowych. W „Chwilce” istniał - wymyślony w 1926 r. przez jedną z czytelniczek dział robótek ręcznych skierowany wyłącznie do czytelniczek, przy czym padło twierdzenie, że wszystkie dziewczynki lubią robótki ${ }^{21}$. Zwracając się więc z prośbą o zrobienie zabawek dla biednych dzieci na Chanukę, redakcja liczyła przede wszystkim na czytelniczki. „Dziewczynki z przedwakacyjnej gminy pracy najraźniej pewnie zabiorą się do roboty"22. Egzaltowany tekst o haftowaniu nadesłała zapewne jedna z czytelniczek:

Miło siedzieć w ciepłym pokoju i haftować. Na dworze szaleje szaruga, a pod moimi dłońmi wykwita wiosna. Dookoła mnie leżą porozrzucane jedwabiste pasma barwnych nici. Z nich zaklęcie wyczarowuje na czerni jedwabne kwiaty. Oto igła mą listki haftuję. Hej, zieleni, zieleni' ${ }^{23}$.

Rolą rodziców było wychowanie dzieci na pobożnych Żydów, przy czym religię traktowano jako element kultywowania tradycji. Dziewczynki wywodzące się z rodzin zachowujących żydowskie obyczaje czuły się lepsze od innych: „Jakże się cieszę, iż jestem córką pobożnego Żyda i jak mi żal tych dzieci, których rodzice nie obchodzą tych świąt"24. Nieznajomość obyczajów żydowskich i lekceważenie żydowskich świąt były bardzo źle widziane. Hanka, bohaterka jednego z opowiadań, zorientowała się, że niemal nic nie wie o swojej religii. Pouczały ją rówieśnice, córki rzemieślnika, choć podkreślały, że brat jako chłopiec lepiej orientuje się w kwestiach religijnych: „Mój brat opowie ci więcej, on wie wszystko o Szewuoth!”25. W identycznym co do wymowy opowiadaniu w „Dzienniczku” dziewczynka po rozmowie ze swoją religijną koleżanką doszła do wniosku, że czegoś jej w życiu i rodzinie brakuje, choć rodzice o nią dbają. Martwiła się, że w jej domu nie ma tego, co najważniejsze: religii i tradycji ${ }^{26}$. Pamiętać trzeba przy tym, że wielu syjonistów nie było religijnych, a więc wymaganie

19 Żywa zabawka, „Chwilka” (30 stycznia 1927), nr 2824, s. 9.

${ }^{20}$ B. H., Jak się Zosia nudziła, „Chwilka” (1 stycznia 1930), nr 3868, s. 8.

${ }^{21}$ Agnieszka Karczewska, Polsko-żydowska republika marzeń. O „Chwilce dla Dzieci i Młodzieży” (1925-1937), Lublin 2015, s. 77.

${ }^{22}$ Konkurs chanukowy, „Chwilka” (24 listopada 1927), nr 3117, s. 10.

${ }^{23}$ Regina Gurfein, Moje hafty, „Chwilka” (8 grudnia 1927), nr 3131, s. 9.

${ }^{24}$ Ruth Wellenfeld , Grzymałów, Pesach i dzieci, „Chwilka” (21 kwietnia 1927), nr 2903, s. 8 .

${ }^{25}$ I. B., Opowieść o dziewczynce, która nie wiedziała, co to jest Szewuot, „Chwilka” (1 czerwca 1927), nr 2945, s. 8.

${ }^{26}$ To, co najważniejsze, „Dzienniczek” (20 września 1928), nr 10, s. 5. 
przestrzegania nakazów judaizmu od dzieci niekoniecznie zgadzało się $\mathrm{z}$ tym, czego uczono je w rodzinie.

Dziewczynki nie miały też żadnych poważniejszych ambicji (poza dotyczącymi pracy dla Palestyny), a dorosłe kobiety występowały w opowiadaniach niemal wyłącznie w roli matek. Nawet te, które pracowały, robiły to tylko w celu utrzymania dziecka. O przyszłości zawodowej dziewczynek nie wspominano. Wzorem była matka wychowująca syna na człowieka, który będzie walczył o swoją ojczyznę. W tekście pod tytułem Jak zostać wielkim człowiekiem? ${ }^{27}$ występowali tylko chłopcy.

Przykładem wzorowej matki była starsza, około siedemdziesięcioletnia kobieta: dostawszy list od dorosłego syna, w którym donosił, że źle się czuje, ruszyła w drogę mimo szabatu. Ale choć wiedziała, że chodzić daleko nie powinna, jednak zrobiła wszystko, aby swój grzech zmniejszyć. Szła piechotą mimo 37 wiorst drogi, nie wzięła laski, parasola ani jedzenia, bo niczego nosić w szabat nie wolno. Nie mogła też nic kupić po drodze, a idąc, odmawiała sobotnie modlitwy ${ }^{28}$.

W tym schemacie kobiety przejawiają swój patriotyzm w sposób konwencjonalny, wychowując synów w miłości ojczyzny, śpiewając im od niemowlęctwa patriotyczne kołysanki ${ }^{29} \mathrm{i}$ zachęcając do pracy dla $\mathrm{Erec}^{30}$. Nie pojawiał się jednak ważny element ideologii syjonistycznej, czyli zachęcanie kobiet do rodzenia dzieci dla ojczyzny, by kolejne pokolenia były coraz liczniejsze i silniejsze. Najwyraźniej nie uważano tego za temat stosowny dla dzieci.

\section{Polityczne buntowniczki}

Na podstawie tego, co zostało napisane wyżej, można by uznać, że wniosek, iż role przypisane dziewczynkom były stereotypowe - powinny być posłuszne, miłe, pomocne, religijne - nie wnosi niczego nowego.

27 B. G., Jak zostać wielkim człowiekiem, „Chwilka” (30 grudnia 1928), nr 3801, s. 9.

${ }_{28}$ Izrael Zangwill, Znieważenie Sabatu, „Chwilka” (1 sierpnia 1929), nr 3720, s. 7.

${ }^{29}$ R. L, Stara piosenka, „Chwilka” (16 stycznia 1930), nr 3883, s. 8.

${ }^{30}$ Taką rolę przypisano kobietom w najwcześniejszych latach istnienia syjonizmu. Maria Antosik-Piela cytuje słowa Theodora Herzla z Die Frauen und der Zionismus, [w:] tenże, Zionistische Schriften, Tel Aviv 1934, s. 433, 436, na temat roli matek: „Matka musi zrozumieć, że [...] syjonizm jest przede wszystkim dla jej dzieci, bo to one są obywatelami przyszłości. [...] Matka, która rozumie syjonizm, będzie go pielęgnować nie tylko dla siebie, ale także dla swoich dzieci. Jest to zatem zajęcie piękne i pożyteczne, nawet gdy musimy na nie poświęcić czas, który normalnie wykorzystalibyśmy na wypoczynek". Antosik-Piela dodaje: „Również według Melzerowej to właśnie kobiety były odpowiedzialne za przekazywanie dzieciom wiedzy na temat historii i kultury żydowskiej, a także za zaznajamianie ich z doktryną syjonistyczną". Maria Antosik-Piela, Tożsamość i ideologia. Literatura polsko-żydowska wobec syjonizmu, Kraków 2020, s. 57. 
Jednak sprawa nie jest taka prosta. W tych samych pismach i do tych samych dziewczynek kierowano bowiem zalecenia całkowicie burzące tradycyjną narrację i dowodzące, że przekaz syjonistycznych pisemek nie był aż tak banalny. Pisma dla dzieci przekazywały bowiem dwa, w gruncie rzeczy sprzeczne wobec siebie wzorce - tradycyjny i syjonistyczny. Syjonizm potrzebował zupełnie innych kobiet i stawiał sobie za cel wychowanie młodego pokolenia dziewcząt tak, aby były zdolne do opuszczenia swojej rodziny i do ciężkiej pracy w Erec.

Zarówno dziewczęta, jak i chłopcy powinni przede wszystkim pracować dla Erec, a zatem uczyć się hebrajskiego ${ }^{31}$, należeć do młodzieżowych organizacji syjonistycznych. Co za tym idzie, wymagano od nich zachowań absolutnie niemieszczących się w ówczesnej konwencji „dobrze wychowanej dziewczynki”.

Nie ma nic dziwnego ani wykraczającego poza ówczesne oczekiwania wobec dzieci w tym, że dziewczęta na łamach „Chwilki” i „Dzienniczka” deklarowały swój patriotyzm zawsze związany z Erec, nigdy z Polską, przy czym ważne było nie tylko samo uczucie, ale i wiedza na temat historii Żydów i Palestyny:

Doczytuję się w historii Ojczyzny mojej, przeżywam wszystko to, co się działo w przeciągu wieków, i myślę, jak cudnie jest, choć często boleśnie, być dzieckiem tego właśnie kraju. Kocham mój kraj za wszystkie bohaterskie wysiłki, za wszystkie męczeństwa jego. Czyż można nie kochać Erec Israel znając jej historię? A teraz, gdy budzi się i odradza na nowo - jakże można z zimną krwią przypatrywać się temu odrodzeniu? ${ }^{32}$.

Same deklaracje to jednak za mało. Oba czasopisma stale motywowały czytelników, w tym dziewczęta, do podejmowania działań na rzecz Erec i alii. Początkowo prawie w każdym numerze wzywano do zbierania pieniędzy na wykup ziemi w Palestynie do „niebieskiej puszki”. To jednak nie wystarczało. „Chwilka” zawstydzała dziewczynki nieznające hebrajskiego, thumaczyła, że nie mają one prawa jechać do Erec. Bohaterce opowiadania ukazuje się we śnie „piękna pani”, ojczysta mowa hebrajska, i mówi: „Póki nie pokochasz mnie całą mocą swego serduszka i nie bacząc na trudności nie nauczysz się odzywać do mnie po hebrajsku, i nie postarasz się mnie zrozumieć, nie mogę cię zabrać do naszej ojczyzny"33.

${ }^{31}$ Zwyczajowo w ortodoksyjnych rodzinach hebrajskiego uczono tylko chłopców.

32 Jema G., III Konkurs literacki „Chwili”: „Dlaczego kocham Palestynę”, wyjątek z pracy..., „Chwilka” (21 sierpnia 1927), nr 3025, s. 9.

${ }_{33}$ Sa-ha, Z listu waszej koleżanki, „Chwilka” (28 lipca 1926), nr 2643, s. 6. 
„Dzienniczek” jeszcze surowiej karcił korespondentki, które przyznały się do nieznajomości ,języka ojczystego":

„Dzienniczek” bardzo się zawstydził, gdyś mu doniosła o tym, że nie znasz ani nie uczysz się języka hebrajskiego. Zapisał cię na osobną listę. Czy nie jest ci żal dziecko, że wielkie skarby Twej ojczystej, rodzimej literatury są Ci na zawsze zamknięte ${ }^{34}$.

Tymczasem hebrajskiego tradycyjnie uczono chłopców, od dziewczynek jego znajomości nie wymagano, a nawet nie zachęcano ich do nauki. Wykraczało to wyraźnie poza zwyczaje wychowania dziewcząt, które w tradycyjnych rodzinach żydowskich nie otrzymywały takiej edukacji religijnej jak chłopcy, którym brak znajomości hebrajskiego uniemożliwiałby studiowanie Talmudu czy Tory.

Grzeczne dziewczynki z „wersji tradycyjnej” bawiły się lalkami i garnkami, kochały ręczne robótki. Tam jednak, gdzie w grę wchodził syjonizm, ich zainteresowania stawały się zupełnie inne. Doskonałym przykładem jest tekst opowiadający o przygotowaniach do Chanuki. Z tej okazji rodzeństwo - dwaj chłopcy i dziewczynka - odtwarzało w mieszkaniu historyczne powstanie Machabeuszy, w ramach którego dzieci zdemolowały pokój i połamały krzesła. Ponieważ to zabawa na wskroś patriotyczna, nie spotkała ich za to nagana ani ze strony matki, ani autorki wierszyka: „Z trudem wielkim dobra matka / Wojsko swe uspokoiła. / Długo cieszy się gromadka, / że tak dzielnie wrogów biła" ${ }^{35}$. W tym wypadku dziewczynka nie musiała już być „grzeczna” i „spokojna” czy pomagać matce przy przygotowaniach do święta. Zabawa przywołująca tradycje narodowe, niezależnie od przebiegu, była nienaganna. Trudno też uznać urządzanie wyborów za zajęcie typowe dla dziewczynek. Znudzone zwykłymi zabawami dziewczynki zdecydowały się urządzić głosowanie. Pomagał im wujek, a kandydatami były fikcyjne osoby uosabiające żydowskie cnoty:

Byli to: Kabed et awicha weimecha (czcij ojca i matkę), Chawer tow (dobry towarzysz), Weahawta 1'reacha kamocha (kochaj bliźniego jak siebie samego), Hewaj mekabel kol ad am b'seiwer panim jafoł (przyjm każdego uprzejmie), Lew tow (miej dobre serce!).

Wygrał ten ostatni, a wujek stwierdził: „Mając dobre serce, będziecie dobrymi Żydami i dobrymi obywatelami” ${ }^{36}$. A więc dziewczynki, znające

${ }_{34}$ Odpowiedzi red. „Dzienniczka”, ,Dzienniczek” (7 czerwca 1928), nr 151, s. 6.

${ }_{35}$ B. G., Wesoła zabawa, „Chwilka” (13 grudnia 1925), nr 2421, s. 6.

${ }_{36}$ Mendel Leib Laszczower, Wybory dzieci, „Chwilka” (5 kwietnia 1928), nr 3248, s. 9. 
język hebrajski, powinny przygotowywać się nie tylko do roli pań domu czy chalucek, ale także do tego, aby być korzystającymi ze swoich praw obywatelkami.

Następny element, zupełnie sprzeczny z wcześniej omawianymi zaleceniami, to stosunek do posłuszeństwa wobec rodziców, który był podstawą wychowania żydowskich dzieci. Jeśli matka nie zgadzała się na naukę hebrajskiego, nie miało to znaczenia, uczyć się należało i tak, ponieważ ojczyzna była ważniejsza od rodziny. Rodzice przestali być najwyższym autorytetem. Dzieci obojga płci miały prawo rozliczać swoich rodziców z tego, czy dobrze spełniali swoje obowiązki narodowe:

Niechaj dzieci zapytają swoich Rodziców, czy świątkując pamięć Judy Makabi i jego braci, byliby zdolni pójść w ich ślady, czy mają w sobie tyle idealizmu i poczucia przynależności do żydostwa, by mogli poświęcić, jeśli nie siebie, to przynajmniej część swego mienia dla umożliwienia odbudowy zmartwychwstającej Ojczyzny [...] A jeśli dzieci nie dostaną na to odpowiedzi, niechaj starają się własne duszyczki tak wykształcić, by same zdolne były do ofiar i by kiedyś ich dzieci nie potrzebowały im stawiać podobnych pytań ${ }^{37}$.

Szczególna krytyka spadła na żydowskie kobiety. Matki, tak podziwiane w poprzedniej narracji, w tej alternatywnej były często ganione za brak zainteresowania Erec i wychowywanie dzieci w duchu asymilacji. Nie mogły już więc być nieomylnymi przewodnikami córek, a te z kolei nie miały już bezwzględnego obowiązku wzorować się na matkach, miały za to prawo podawać w wątpliwość, czy są właściwie wychowywane. Wspomniana już wyżej Hanka, która nie zna żydowskich obyczajów, zastanawia się nad swoim wychowaniem i o swoje braki w wiedzy dyskretnie oskarża matkę: „O tem jeszcze nigdy nie słyszałam. W moich książkach tego nie ma. Mamusia czyta mi bajeczki o Czerwonym Kapturku, o Jasiu i Małgosi, o dziewczynce z zapałkami”38. W 1928 r. pisano o tym wprost:

Przy końcu chcieliśmy powiedzieć słów parę Mamusiom Waszym: „Chwilka” pragnie wedle wszelkich sil i możności wskazać Wam najczystszą i najlepszą drogę, po której kroczyć winniście, lecz „Chwilka” jest smutna, samotna i opuszczona, jeżeli nie czuje tego współdziałania, tej współpracy z domem - w pierwszym rzędzie zaś z Matką, która jest sercem i duszą wszystkiego, co się w domu dzieje. Nie wiemy, czy w jeszcze jednym narodzie świata Matka ma tak wielkie i odpowiedzialne za-

${ }^{37}$ Inż. B. C. (Haifa), Wieczór chanukowy, „Chwilka” (22 grudnia 1927), nr 3145, s. 7.

${ }^{38}$ I. B., Opowieść o dziewczynce..., s. 8. 
danie do spełnienia, jak właśnie Matka żydowska. Od niej zależy utrzymanie Was w ukochaniu i zrozumieniu dla starej, pięknej tradycji naszej i ideałów wyzwolenia ${ }^{39}$.

Powyższe zalecenie odnosiło się do matek zarówno córek, jak i synów, ale oczywiste było, że według redakcji „Chwilki” to dom jest zobowiązany dostosować się do syjonistycznych ideałów pisma, a nie odwrotnie; dzieci zaś powinny postępować zgodnie z zaleceniami „Chwilki” niezależnie od tego, co słyszą w domu. Redakcja często wręcz namawia czytelników, aby słuchali osób spoza rodziny, ideowych syjonistów, czego efektem jest wybieranie przez dziewczęta pracy w Erec nawet wbrew rodzicom.

Miłość ojczyzny wpajają dziewczynkom osoby obce - działacze syjonistyczni, wychowawcy na szomrowych koloniach - one też namawiają do pracy dla organizacji. Oto opowiadanie o jednej z takich dziewcząt, Nusi, która wyjechała z powodu wątłego zdrowia do pensjonatu:

Nadzór nad dziewczynkami ma p. Anna [...] Ta, przez umiejętnie przeprowadzane pogadanki, wszczepiała dziewczątkom miłość do Ojczyzny i chęć do pracy dla Niej. Gdy więc Nusia, będąc pod wrażeniem słów p. Ani, prosiła, by jej wskazać, jak pracować dla Ojczyzny, rzekła opiekunka: - „Ty, Nusia, i inne dzieci w twoim wieku możecie pracować tylko na jednem polu: zbierać fundusze na Keren Kajemeth Leisrael. [...] Każde dziecko więc powinno zbierać pieniądze na ten cel, a w jaki sposób, niechaj samo postanowi - swe postanowienie w czyn wprowadzi, a dowiedzie, że słusznie nosi miano potomków Izraela ${ }^{40}$.

Nusia po powrocie $\mathrm{z}$ wakacji spoważniała, z koleżankami pracowała i oszczędzała, aby wpłacać pieniądze, zapisała się na kurs hebrajskiego i do organizacji szomrowej, marzyła o wyjeździe do Palestyny. Redakcja zachęcała dziewczęta do wstępowania do organizacji syjonistycznych i pokazywała, jak mogą to zrobić i pod czyim kierownictwem:

Delegatka światowej organizacji kobiet żydowskich p. Bella Pewznerowa przebywa obecnie we Lwowie. Stara się ona podczas swego pobytu w Polsce o wzbudzenie większego zrozumienia wśród kobiet żydowskich dla wielkich obowiązków, które ciążą na nich wobec odradzającej się Ojczyzny. Także dziewczęta mogą współpracować w tem wielkim dziele i organizować się jako młodsze grupy „Wiza”. Po wszelkie wskazówki możecie się zwrócić do redakcji, która chętnie pójdzie Wam na rękę ${ }^{41}$.

${ }^{39}$ Rozpoczynamy nowy rok pracy, „Chwilka” (4 grudnia 1928), nr 3483, s. 7, 9.

40 Adela Hartensteinówna, Zrozumienie sprawy, Chwilka” (23 kwietnia 1930), nr 3978, s. 9.

${ }^{41}$ Dla dziewcząt, „Chwilka” (31 stycznia 1929), nr 3541, s. 10. 
Zatem dziewczynki, podobnie jak chłopcy, powinny należeć do organizacji szomrowych, a co za tym idzie - jeździć na obozy szomrowe, a tam wykazywać się jak największą samodzielnością. Miały być silne, nie skarżyć się, ale pracować dla ojczyzny. „Nie chcemy opłakiwać i opiewać »jękiem i skowytem « życia w golusie, lecz hartować serca do pracy na wolności”"42 odpowiadała redakcja „Chwilki” czytelniczce, która nadesłała swoją pracę. Sprzeczność z zaleceniami dla „grzecznych dziewczynek” bywała uderzająca - o ile te pierwsze skłaniano do przestrzegania żydowskich obyczajów i religii, o tyle te drugie, szomerki, uczestniczyły w sobotnich wycieczkach organizacyjnych połączonych z musztrą ${ }^{43}$. Wobec pracy dla Erec dziewczęta i chłopcy nie tylko stają się sobie równi, ale mają także takie same możliwości i obowiązki, a dziewczyny mogą jak najbardziej wykonywać „męskie” prace czy zachowywać się tak jak chłopcy. W „Chwilce” drukowano nadesłane przez dzieci utwory dotyczące Palestyny. I tu także dziewczynki, na równi z chłopcami, marzyły o pracy dla Erec:

„A wy dziewczęta, dokąd pędzicie / Wśród kolców i ostrej zimy?” / „Do Erec idziem! Na nowe życie! / Kolców się nie boimy! / Przed nami życie! Jesteśmy młodzi! / Kraj cały odbudujemy!" ${ }^{4}$.

O życiu w Palestynie marzyły nawet najmłodsze dziewczynki. Mała Ela, która bawiła się globusem w gabinecie ojca, nie tylko potrafiła wskazać na nim różne miejsca, ale zapytana przez babkę, gdzie będzie mieszkać, jak dorośnie, nie zawahała się: „Mała rozumie jasny błysk w oczach babci. Obraca lekko globus i wymownie milcząc patrzy na jasny skrawek ziemi z napisem »Erez«. Babcia jest strasznie dumna z Eli” ${ }^{45}$. Było to odejście od tradycyjnego obowiązku dzieci, a przede wszystkim córek, zapewnienia rodzicom opieki na starość. Nawet dla kobiet powinności wobec rodziny były drugorzędne wobec obowiązków względem ojczyzny.

Charakterystyczne dla „Dzienniczka” było ignorowanie jakiejkolwiek różnicy płci, gdy w grę wchodziła praca w Erec. Nawet siła fizyczna nie była istotna. Dziennikarz tego pisma w reportażu z kibucu podkreślał ciężką pracę kobiet: „Chaluca około dwudziestoletnia siedziała na ziemi, otoczona gromadą kamieni, prawdziwymi kamieniami, od których ręce kaleczeją. I za każdym razem podnosi miot i bije z siłą w kamienie, które

${ }^{42}$ Odpowiedzi Redakcji, „Chwilka” (5 czerwca 1930), nr 4020, s. 10.

43 Judyta Reichówna, Wycieczka na Panieńskie skały, „Dzienniczek” (1928), nr 8.

44 Anka Silberman (Stanisławów), Po ciernistej drodze, „Chwilka” (18 grudnia 1926), nr 2784, s. 10.

45 Anda Eckerówna, Globus, „Chwilka” (12 grudnia 1929), nr 3850, s. 8. 


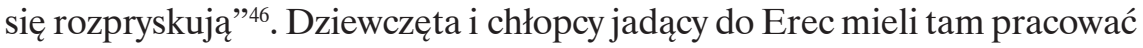
tak samo i na takich samych stanowiskach.

Nietrudno zauważyć, że dorośli autorzy „Chwilki” i „Dzienniczka” nie potrafili połączyć ze sobą tradycji, która wymagała wychowywania dziewczynek na pobożne żony i matki, z nowoczesnością syjonizmu, który z tą właśnie tradycją chciał zerwać: „Jako ideologia syjonizm postanowił stworzyć nowy typ żydowskich kobiet w sferze ideologicznej, psychologicznej i fizycznej" ${ }^{47}$. Przekaz badanych pism był zatem niespójny wewnętrznie.

W rzeczywistości w odniesieniu do dziewczynek z rodzin syjonistycznych trudno nawet mówić o dwoistości przekazu i podwójnych, sprzecznych ze sobą wymaganiach ${ }^{48}$. Było to jeszcze bardziej skomplikowane. Socjalizacja odbywała się przecież także w szkole. Tylko nieliczne dziewczęta uczyły się w prywatnych szkołach hebrajskich, w których program edukacyjny był skierowany na wychowanie młodych syjonistek, a i to często w sposób znacznie mniej jednoznaczny, niż czyniły to „Chwilka” i „Dzienniczek”. Jak stwierdza Kamil Kijek, nawet w szkołach Tarbutu polska literatura i język polski były coraz istotniejsze. „Zdominowany przez klasę średnią syjonizm, nabierał wraz jej z akulturacją coraz bardziej "polskiego « charakteru"49.

Zasadnicza większość dzieci uczęszczała do szkół polskich, w których przekazywany był im polski patriotyzm i polska kultura. Nawet uczennice szkół hebrajskich na przedmiotach „nieżydowskich” otrzymywały taki przekaz, bo realizowany był tam program zatwierdzony przez Ministerstwo Wyznań Religijnych i Oświecenia Publicznego (MWRiOP). Był on

${ }^{46}$ Wrażenia z kibucu Kłossowia. Przekład z hebrajskiego, „Dzienniczek” (8 marca 1930), s. 12.

${ }^{47}$ Jolanta Mickute, Making of the Zionist Woman: Zionist Discourse on the Jewish Woman's Body and Selfhood in Interwar Poland, East European Politics and Societies, http://eep.sagepub.com/content/28/1/137 [dostęp: 2 lipca 2021].

48 Ta część stanowi swoistą polemikę z ustaleniami, jakie zamieściłam w moim artykule Not Just „Mały Przeglad” sprzed paru lat. „Można by się jednak zastanowić, czy »Dzienniczek « nie poszedł w propagowaniu równouprawnienia o krok dalej. Wprawdzie nie ma w nim dyskusji o roli kobiet, nie ma artykułów bezpośrednio poświęconych temu tematowi, ale rzeczywistość, która wyłania się z tekstów na zupełnie inne tematy, jest jednoznaczna. Nie ma różnic ani w celach życiowych, ani w zadaniach, ani w możliwościach obu płci. $\mathrm{W}$ »Dzienniczku « bowiem dziewczęta i chłopcy jadący do Erec mają wyznaczone właściwie identyczne role. Jeśli równouprawnienie nie sprawdza się w praktyce, dochodzi do dyskryminacji dziewcząt - przedstawiane jest to jako krzywda, błąd popełniony przez organizatorów”. Anna Landau-Czajka, Not Just „Maty Przeglad”: The Ideals and Educational Values Expressed in Jewish Polish-Language Journals for Children and Young Adults, [w:] New Directions in the History of the Jews in the Polish Lands, red. Antony Polonsky, Hanna Wegrzynek, Andrzej Żbikowski, Boston 2018. Okazuje się jednak, że równouprawnienie w „Dzienniczku" pojawiało się tylko tam, gdzie mowa była o pracy dla Erec.

${ }^{49}$ Kijek, Dzieci modernizmu..., s. 224. 
w oczywisty sposób niespójny z przekazem „Chwilki” i „Dzienniczka” dla młodych chalucek.

I wreszcie religia. Kolejny wzorzec często przekazywany był dziewczętom przez pokolenia dziadków, nierzadko wywodzących się z ortodoksyjnych rodzin. Nie tylko z przerażeniem patrzyli oni na polonizację dzieci i wnuków, ale byli oburzeni świeckim obliczem syjonizmu, demoralizacją dziewczynek zaangażowanych w koedukacyjny projekt, w dodatku sprzeczny z judaizmem, bo przecież państwo żydowskie mógł wskrzesić tylko Mesjasz, a nie ludzie i ich organizacje polityczne. Dziadkowie oczekiwali od dziewczynek prawdziwej pobożności, przygotowania się do szybkiego zamążpójścia i podjęcia roli tradycyjnej żony i matki.

Jest oczywiste, że żadna dziewczynka nie mogła się podporządkować tak sprzecznym wymaganiom. Cokolwiek robiła, była skazana na krytykę. Być może właśnie dlatego, gdy same dziewczęta zabierały głos, widać, że w tej sytuacji decydowały się na samodzielność i wybieranie - być może nie zawsze w pełni świadome - tego, co uważały za najlepsze dla siebie. I nie było to posłuszeństwo.

\section{„Mały Przegląd”. Rzeczywistość}

Do „Małego Przeglądu” pisały dzieci obu płci, w redakcji zasiadali zarówno chłopcy, jak i dziewczynki, byli reporterami, prowadzili lokalne koła ${ }^{50}$. Piętnastoletnia Madzia Marcuse sprawowała funkcję sekretarza redakcji i przyjmowała interesantów. Działo się tak, mimo że w pierwszych numerach, w których Korczak był autorem tekstów i odpowiadał na listy dzieci (później tego zaniechano), widać, iż poglądy redaktora były bardziej konserwatywne niż czytelników. Na korespondencję, w której znalazło się życzenie: „Żeby chłopcy z dziewczętami razem wszystkich zabaw i sportów używali”, odpowiedział: „Trudno będzie. Bo po pierwsze, nie wszystkie sporty są jednakowo zdrowe dla chłopców i dziewcząt, a po drugie, jeżeli który chłopiec więcej bawi się z dziewczynkami, zaczynają mu dokuczać i wyśmiewać" 51 .

O ile w „Chwilce” i „Dzienniczku” problem różnic w zachowaniu obu płci i wymaganiach wobec nich występował tylko marginalnie, o tyle

${ }^{50}$ Informacje na temat redakcji, kół, reporterów można znaleźć w: Landau-Czajka, Wielki „Maly Przeglą"...

51 Janusz Korczak, Odpowiedź na listy (poczta druga). Razem, „MP” (22 października 1926), nr 290, s. 5. 
w „Małym Przeglądzie” w pierwszych latach był niezwykle często poruszany. Wielka liczba listów na ten temat świadczy o tym, jak ważny był to problem dla dzieci. W latach 1927-1928 toczyła się dyskusja dotycząca dziewczynek i chłopców. Dyskutowano na temat ich wad i zalet, wzajemnego odnoszenia się do siebie, równouprawnienia.

Zapoczątkował ją list do redakcji chłopca przedstawiającego się jako „wróg kobiet”. Pisał w nim, że chłopcy powszechnie uznawani są za niegrzecznych i jest to częściowo prawda. Ale dziewczynki, postrzegane inaczej, wcale nie są lepsze:

niby niewinne duszyczki, które zdają się być ciche jak muchy na ścianie. O nie potrafią swym piszczącym głosikiem i głośnym płaczem niebo i ziemię poruszyć: niejeden chłopiec ucierpiał od skarg dziewczęcych i łez, które tworzą jeziora pod ławkami. Ileż to morałów my, nieszczęśliwi chłopcy, wysłuchiwać musimy! ${ }^{52}$.

W obronie dziewczynek wystąpił Stefek i rozpętała się dyskusja. W odpowiedzi przyszło ponad dwadzieścia listów. Redakcja rozdzieliła je według płci. W listach chłopców pojawiały się głosy, że dziewczynki są nieszczere, udają, plotkują, że mają więcej wad niż chłopcy. Większość chłopców oburzała się na Stefka, że uważa dziewczęta za lepsze od chłopców - autorzy listów twierdzili, że sami lubią dziewczynki (choć nie wszystkie), ale chłopak powinien bronić „swoich”. Dziewczynki odpowiadały, że chłopcy im dokuczają, dają gorsze role w zabawach, uważają za istoty niższe od siebie. Jednak najważniejsze jest to, jak oceniały same siebie. W tym przypadku widać powielanie stereotypu dziewcząt jako osób niezbyt rozgarniętych, niesamodzielnych, ale przyjaznych światu:

Wadą dziewczynek jest, że mają słabą wolę, łatwo upadają na duchu, nie lubią się zastanawiać nad czemś ważnem. Każda dziewczynka jest lekkomyślna i mało myśląca. [...] Nasze zalety przynoszą światu dużo dobrego. Dzięki nam rozszerza się przed nimi duży, pełen uroku i cudów świat ${ }^{53}$.

Korczak najwyraźniej bardzo zainteresowany był dyskusją i w „Małym Przeglądzie" ukazało się podsumowanie, w którym wymieniano, co o płci swojej i przeciwnej sądzili jej uczestnicy, jakie zalety i wady wymieniali. Oto jak oceniały się same dziewczynki:

Wady, które dziewczynki przypisują sobie: Kokietki, stroją się, nie lubią ruchliwych zabaw, niedołężne, tchórzliwe, beksy, plotkarki, szepcą po kątach, nieszcze-

\footnotetext{
52 Ach, te dziewczęta (Wróg kobiet), „MP” (27 maja 1927), nr 143, s. 7.

53 Stefek obrońca dziewcząt (dokończenie), „MP” (24 lutego 1928), nr 55, s. 5.
} 
re, kumoszki, niekoleżeńskie, obłudne, skarżypyty, złośnice, złośliwe, zazdrosne, kłamczuchy, udawalskie, skromnisie, niewiniątki [sic!], udają delikatne, przesadne, ceremonialne, mało głębokie, nie zastanawiają się [...]. Zalety, które dziewczynki przypisują sobie: Miłe, wdzięczne, przyjacielskie, serdeczne, miłosierne, dobrze wychowane, grzeczne, uczynne, cenią przyjaźń, poświęcające, szlachetne, dobre, koleżeńskie, delikatne, potulne, wstydliwe, nabożne, pilne, uczą się dobrze, dają dobry przykład chłopcom, sprawiedliwe, uczciwe, gospodarne, inteligentne, myślące, dzielne, mądre, wesołe, pogodne, proste $^{54}$.

Na pierwszy rzut oka wydaje się to kolejnym powtarzaniem tradycyjnych wyobrażeń. Należy jednak zauważyć, że pewne cenione zalety kobiece skromność, delikatność, niewinność (także udawana), niechęć do zbyt żywiołowych zabaw - zaliczone zostały do cech niepożądanych. Wśród cech pożądanych pojawiły się jednak i takie, które w listach właściwie nie występowały - pobożność, potulność, wstydliwość - z czego wynikałoby, że jest prawdopodobne, iż listów dzieci z bardziej tradycyjnych domów często nie publikowano.

Mimo podsumowania nie zdecydowano się zakończyć dyskusji. Temat okazał się bardzo ważny, listy dzieci przychodziły dalej. W dwóch kolejnych numerach zgrupowano korespondencję, w której chłopcy wyrażali swoje opinie o dziewczynkach, a dziewczynki o chłopcach. Oprócz wielu poruszanych już wcześniej tematów znalazło się kilka interesujących wypowiedzi, zwykle dotyczących wzajemnej przyjaźni. Autorzy listów najwyraźniej podzieleni byli na dwa obozy.

Pierwszy obóz nie przeczył istnieniu pewnych różnic, ale nie uważał, aby były one istotne w przyjaźni. Borys negował nawet i te różnice - nie tylko dziewczynki udają delikatniejsze, chłopcy też czasem pozują, udają dorosłych na wieczorkach tanecznych. Bywają nieszczere dziewczęta, ale są i tacy chłopcy. „A więc niech żyje przyjaźń między oba [sic!'] obozami”"55. Podobnie sądził Izaak, który podkreślał, że choć chłopcy są silniejsi, a dziewczynki milsze, ale nie jest to żaden powód, aby nie można było

${ }^{54}$ Wady $i$ zalety chłopców i dziewczynek (Z polemiki o list Stefka), „MP” (13 kwietnia 1928), nr 102, s. 8. Chłopcy podawali następujące wady i zalety dziewczynek: „Wady dziewczynek [...] udawalskie, nieszczere, zazdrosne, mają fochy, ironiczne, szydzą, brak własnego zdania, niesamodzielne, skarżuchy, dumne, sprzedajne, puste, nielogiczne, sentymentalne, pyszne, plotkarki, kokietki, gaduły, aroganckie, dokuczliwe, mówią sekrety, mówią do ucha, niewiniątka, mówią tylko o chłopcach, gadatliwe, udawalskie, obraźliwe, gapy i ciapy, małpują, chwalą się [...]. Zalety dziewczynek: spokojne, miłe, wesołe, pilne, dzielą się uczuciami, opiekują się, szczere, uczciwe, wstydliwe i czułe".

55 Chłopcy o dziewczynkach, „MP” (19 października 1928), nr 288, s. 7. 
zostać kolegami. Przecież różnica nie jest istotna, nawet o kraj walczą nie tylko mężczyźni, lecz i kobiety.

Drugi obóz stwierdzał, że w zasadzie różnice są nieprzekraczalne z wyjątkiem wypadków, gdy dzieci nie odpowiadają stereotypom swojej płci. Josek i Adek uważali, że między dziećmi różnej płci istnieje zasadnicza różnica - dziewczynki są spokojne, chłopcy hałaśliwi, dziewczynki dobrze się czują w domu, chłopcy - jak w klatce; Adek twierdził, że dziewczynki czytają „brukowe świstki”, a chłopcy „,arcydzieła awanturnicze”. Ich inna natura nie pozwalała na przyjaźń. Zresztą ani jedna, ani druga strona sobie tego nie życzyła. Ale istniały wyjątki. Zdaniem Joska to „zuch dziewczyny”, którym odpowiada towarzystwo kolegów, i „ciapy, ciamajdy, łamagi”, które wolą koleżanki. Adek uznał, że przyjaźnić się z dziewczętami mogą tylko chłopcy nielubiący sportu, spokojni i poważni. Widać tu wyraźnie, że zabawa z chłopcami była dla dziewczynki nobilitująca, a zabawa z dziewczynkami deprecjonowała - przynajmniej w oczach Joska - chłopca.

Jak widać, również korespondenci „Małego Przeglądu” powielali stereotypy, z tym że częściej czynili to chłopcy niż dziewczęta, które z nimi polemizowały. „Eljasz uważa, że nauka nie zajmuje dziewcząt, które myślą tylko o strojach, a Rachela uważa, że chłopcy tak samo dbają o urodę i ładne ubranie" $" 56$.

Korespondentki „Małego Przeglądu” zauważały dyskryminację kobiet i dziewcząt w różnych dziedzinach życia i skarżyły się na to zjawisko. Przede wszystkim wiele z nich nie czuło się bezpiecznie, widząc, że nie mogą szukać pomocy u dorosłych, gdy są zaczepiane przez chłopaków. Było to bowiem uznawane za normalne zachowanie, nawet jeśli łączyło się z agresją. Gdy na ulicy chłopiec uderzył pięścią przechodzące dziewczęta, stojący obok policjant śmiał się i nie interweniował ${ }^{57}$.

Innym poruszanym przez czytelniczki problemem były odmienne wymagania, przy czym od dziewczynek dorośli wymagali więcej. Korespondentki podkreślały, że charakter i zachowanie dziecka nie zależy od płci, ale uznaje się, iż dziewczęta zawsze powinny być grzeczne i uprzejme Młoda, dziesięcioletnia aktorka wyznaje w wywiadzie: „Dziewczynki nawet na scenie muszą być grzeczniejsze od chłopców - wolę grać role chłopców"58.

${ }^{56}$ Z kraju, „MP” (13 stycznia 1928), nr 13, s. 5.

57 (Mania), Chłopcy i dziewczęta, „MP” (10 czerwca 1927), nr 157.

58 Jawan, Jackie Coogan w sukience. Wywiad „Małego Przegladu” z najmtodsza artystka w Warszawie, Ninka Wilińska, „MP” (22 października 1926), nr 290, s. 6. 
W jednym z kolejnych numerów opublikowano list dziewczynek, które pojechały do parku dorożką i bały się, że to się wyda. Oto fragment:

Nie ma zgody między chłopcami i dziewczynkami. Dziewczynki skarżą się, że chłopcy łobuzy, a chłopcy mówią, że dziewczynki gamajdy. Ale nie wiedzą, jak dziewczynki są skrępowane, ile razy dziennie słyszą, że co innego chłopiec; dziewczynce nie wypada, nieładnie, nie wolno. - Są przecież spokojni między chłopcami, są łobuziaki między dziewczętami. Chłopcom nie zabraniają przynajmniej śmiać się i biegać. [...] A potem dziwią się, że dziewczynki są sztywne i sztuczne, to znaczy - nieszczere. Bo ciągle tylko trzymane pod grozą - i nawet „niewinny” żart wydaje się wykroczeniem, jeżeli nie - zgoła występkiem ${ }^{59}$.

Odpowiedź Korczaka na tę skargę była bardzo enigmatyczna, przy czym skupił się na jeździe dorożką, a nie na niewątpliwie słusznych przemyśleniach. Odesłał korespondentki do wcześniejszego artykułu, w którym pisał: „Przeszkadzają starzy dobrze się bawić młodym. Ale jak bardzo sami sobie przeszkadzamy" ${ }^{\prime 0}$. Tak czy inaczej w kwestii odmiennych wymagań nie zajął stanowiska. A temat musiał być ważny, bo pojawiał się również w następnych latach. W 1927 r. korespondentka skarżyła się, że złości się, ilekroć słyszy zdanie „nie wypada”, i zastanawia się, dlaczego dziewczynkom nie pozwala się być wesołymi ${ }^{11}$. Niewątpliwie dotyczyło to zarówno polskich, jak i żydowskich dziewczynek, bo uwagę zwracali im także przypadkowi przechodnie, nieznający narodowości dzieci.

Inne wymagania dostrzegali także chłopcy. Stefek, zwany „obrońcą dziewcząt", odpowiadając na polemikę z jego listem, pisał, że prawdą jest, iż popchnięta dziewczynka się drze, a chłopak bierze się do bicia. Ale przyczyną nie jest tylko to, że dziewczynki są słabsze: „Ale pomyślcie tylko, ile dziewczynkom wkładają w domu do głów, że nie wolno, brzydko, niegrzecznie się bić” "22. Innymi słowy, zauważył, że dziewczynki zachowywały się inaczej nie z powodu swojej płci, lecz ze względu na odmienne wychowanie.

Dziewczynki dosyć często narzekały, że muszą słuchać poleceń dorosłych, którzy ich nie rozumieją, choć z drugiej strony dotyczyło to wszystkich dzieci - niezależnie od płci. Nie wspominały jednak o żadnej dyskryminacji w szkole (poza wymaganiem większej grzeczności). W tym

${ }^{59}$ Nie wypada, „MP” (24 grudnia 1926), nr 353, s. 5.

${ }^{60}$ K., Młodzież dla młodzieży (Starszy Pan na koncercie), „MP” (12 listopada 1926), nr 311, s. 7.

${ }^{61}$ (Ada), Nie wypada, „MP” (11 lutego 1927), nr 42.

62 Stefek, List Stefka - obrońcy dziewczynek, „MP” (16 marca 1928), nr 76, s. 9. 
wypadku dyskryminowani czuli się czasem chłopcy. Bardzo ciekawy jest opis konfliktu w jednej z klas szkoły powszechnej:

Chłopcy, widząc, że dziewczynki stanowią większość w samorządzie, oburzyli się i postanowili zaprotestować. Urządzili naradę bez udziału dziewczynek. Dziewczynki, widząc naradę chłopców, postąpiły tak samo. [...] Przyczyną niezadowolenia chłopców było: niesolidarność dziewczynek w stosunku do chłopców, niewyjawianie tajemnic, a także to, że dziewczynki nie chcą z nimi razem siedzieć. [...] w końcu zdołano przekonać chłopców, że zarzuty ich są bezpodstawne ${ }^{63}$.

Najwyraźniej to chłopcy mieli mniejszy dostęp do „władzy” i uważali, że dziewczynki nie chcą się z nimi przyjaźnić.

Specyficzna była sytuacja żydowskich dziewcząt z bardziej tradycyjnych rodzin w związku z nauką szkolną. W tym wyjątkowym wypadku dyskryminacja chłopców była rzeczywista. Istotnie, podczas gdy synów często posyłano do chederu, córki uczyły się w polskich i żydowskich szkołach świeckich, z reguły nowocześniejszych i dających bardziej wszechstronne wykształcenie. Zatem - przynajmniej na najwcześniejszym etapie kształcenia -to chłopcy zazdrościli dziewczętom tej możliwości: „Nie chcę chodzić do chederu. Mam koleżankę Niunię, która jest w drugim oddziale szkoły powszechnej. Ja chodzę do chederu, ale chcę się uczyć razem z Niunią"64 skarżył się Chaimek.

Znacznie starszy od niego korespondent pisał wprost o nierówności w traktowaniu synów i córek - ale na korzyść tych ostatnich: „Chciałbym zadać jedno pytanie, może naiwne: dlaczego robicie, rodzice, różnicę między synami a córkami? [...] pozwalając uczyć się córce, synów odsuwacie od wykształcenia. Córki mają inne wyobrażenie o świecie, inny zgoła jest ich sąd o życiu" "65. Autor tego wezwania do ojców radził się zastanowić, jak dalej potoczy się życie dzieci - po zamążpójściu okaże się nagle, że mąż to prostak, a żona jest uczona.

Niezależnie od tego, co przedstawiały pisemka i książeczki dla dzieci, wydaje się, że ścisły podział na zabawy „chłopięce” i „dziewczęce” był częściowo mitem. Rzeczywiście lalkami bawiły się tylko dziewczęta. Ale już wspólne zabawy „dziewczęce” - w „sklep”, „rodzinę”, a także „chłopięce” - w „Indian”, „policjantów i złodziei” czy w „wojnę” - były jak

63 (Ada), Przeprosiny, „MP” (8 kwietnia 1927), nr 98, s. 6.

${ }^{64}$ Chaimek, Chaimek i Niunia, „MP” (10 stycznia 1930), nr 10, s. 4.

${ }^{65}$ Głos młodzieży do niektórych ojców, „MP” (24 stycznia 1930), nr 124 [błędny nr] (2459), s. 2. 
najbardziej koedukacyjne ${ }^{66}$. Zdarzały się jednak skargi na to, że ról w tych zabawach nie rozdzielano sprawiedliwie:

Kiedyśmy się bawili w Indian, chłopcy przywiązali nas do drzewa i walili prętami, a myśmy tylko krzyczały, żeby nas przyszli odwiązać. Potem chłopcy wszystkim rozpowiadali, żeśmy beczały. I oni zawsze chwalą się, że jak dorosną, będą w wojsku. A kiedy bawimy się w wojnę, oni są żołnierzami, a nam każą być niewolnicami ${ }^{67}$.

Nie była to jednak reguła, role bywały rozdzielane i tak, że dziewczynki miały przewagę. Na przykład: „W lecie bawiliśmy się w wojnę. Chłopcy tworzyli jeden obóz, a dziewczęta drugi. Chłopcy byli Arabami, a dziewczynki - Żydami [...] Arabowie wpadli do dołu, a Żydzi zwyciężyli" ${ }^{\circ}$.

Interesujące jest, jak wiele opisów bójek - i to często bójek z chłopcami - można znaleźć w listach. To ten element rzeczywistości, który przez dorosłych nie był zauważany. Dziewczynki w książkach czy czytankach bywały ofiarami, nigdy napastnikami, raczej też nie broniły się same. Tymczasem dziewczynki stosunkowo często czynnie broniły koleżanek lub samych siebie. Na ratunek dziewczynce, której chłopiec zabrał sznur do zabawy, ruszyły dwie koleżanki: „Długo biłyśmy się z nim, wreszcie położyłyśmy go na ziemi, wyrywając sznur”"99.

„Mały Przegląd” drukował korespondencje, które dla pobożnych żydowskich rodziców byłyby nie do przyjęcia, a dotyczyły koedukacji. Zaskakująco często dziewczynki i chłopcy przyjaźnili się czy siedzieli w szkole w jednej ławce ${ }^{70}$. Sporadycznie tylko narzekano na to: „Rózia mówi, że w szkole byłoby dobrze, gdyby chłopcy nie uczyli się razem z dziewczynkami"’11.

Bardzo ciekawą prawidłowość zauważył jeden z chłopców. Młodsze dziewczynki, do dziesięciu lat, potrafią być dobrymi kolegami i przyjaźnić się, potem zaczynają się od chłopców odsuwać, najpierw ochładzają kontakty, a potem zrywają znajomości. Co ciekawe, autor nie łączył tego ani z dojrzewaniem, ani - co istotniejsze - z zasadami religijnymi, $w$ tradycyjnym judaizmie oddzielającymi od siebie obie płcie ${ }^{72}$. Nie zawsze musiała być to prawda, bo przyjaźnie zdarzały się także w gimnazjach koedukacyjnych, przy czym chłopcy nie odgrywali w nich ważniejszych

${ }^{66}$ O zabawach (temat jesienny), „MP” (21 marca 1930), nr 80, s. 2-3.

${ }^{67}$ Stefek obrońca dziewcząt (dokończenie)..., s. 5.

${ }^{68}$ Stefka z Nalewek, O zabawach (temat jesienny), „MP” (21 marca 1930), nr 80, s. 3.

${ }^{69}$ Sala i Rachela, Wielka awantura, ,MP” (1 listopada 1929), nr 299, s. 3.

${ }^{70}$ Państwowe szkoły powszechne były zazwyczaj koedukacyjne.

${ }^{71}$ Z kraju, ,MP” (21 lutego 1930), nr 52, s. 4.

72 Stefek, obrońca dziewcząt, „MP” (17 lutego 1928), nr 48, s. 6. 
ról. Na przykład: „Dziewczęta zajmują u nas bardzo odpowiedzialne stanowiska, często pomagają chłopcom w nauce i chodzą do nich do domu, co bynajmniej nie jest czynem niemoralnym"73.

Na zajęciach sportowych „Makabi” ćwiczono razem, polecenia wydawane dzieciom były takie same. Na drzewa po jabłka wspinali się wszyscy, nawet najmłodsza, sześcioletnia $\mathrm{Ala}^{74}$. Do szomrów także zapisywali się i dziewczynki, i chłopcy, jednak tu drużyny, choć mające takie same cele i metody działania, były podzielone.

Redakcja szła nawet dalej. Dwoje dzieci - Mietek i Ewa - skarżyło się, że przy zabawie w „fanty” wypadło, iż chłopiec ma trzykrotnie pocałować Ewę, a ponieważ się sprzeciwił, nie zwrócono mu fantu - zegarka. Prosili redakcję o wyrażenie opinii w tej sprawie. Odpowiedź brzmiała: „Mietek i Ewa powinni się pocałować. Redakcja" 75 . Zdecydowanie nie była to rada, która wpisuje się w nakazy religii żydowskiej ani nawet w powszechne wówczas, także w środowisku polskim, zasady norm obyczajowych.

Wyraźniej niż przy innych zjawiskach w przypadku mieszanej przyjaźni widoczne było ścieranie się tradycyjnych norm z rzeczywistością. Nie zawsze jednak rodzice akceptowali wspólne zabawy. W 1926 r. korespondentka skarżyła się: „Mama mnie biła, że się bawię z chłopakami”" Jest to jednak wyjątek, podobnych problemów raczej nie sygnalizowano. Z opisów klas, wspólnych zabaw, przyjęć urodzinowych wynika, że chłopcy i dziewczynki nie byli odseparowani, koleżeństwo kwitło.

Gdy jednak dzieci pisały o obowiązujących w dziecięcych grupach normach, stereotyp niewłaściwości takiego zachowania miewa się jeszcze dobrze. Dzieci opisywały wówczas „typowe” reakcje innych. Sporo osób zauważało, ,że chłopiec przyjaźniący się z dziewczynką staje się pośmiewiskiem kolegów” "77. „Prawie każdy sztubak, gdy dowie się, że kolega przyjaźni się albo tylko nawet zna się z dziewczynką, rozpowiada to wszystkim kolegom, wystawia danego chłopca na pośmiewisko i przezywa różnymi przezwiskami"78. Rzadko spotyka się odwrotną sytuację, gdy przyjaźn z chłopcem jest problemem dla dziewczynki, choć i takie zjawisko czasem jest sygnalizowane. Jedna z korespondentek dziwiła się,

${ }^{73}$ Stefek obrońca dziewcząt (dokończenie)..., s. 5.

74 Jawan, Godzina na popisie sportowym, „MP” (13[?] maja 1927), nr 131, s. 8.

${ }^{75}$ Mietek i Ewa, Pocatunek za fant, ,MP” (22 listopada 1929), nr 320, s. 3.

76 Wiadomości bieżace, „MP” (10 grudnia 1926), nr 339, s. 4.

77 Podziękowanie, ,MP” (3 lutego 1928), nr 34, s. 8.

78 Stefek obrońca dziewcząt (dokończenie)..., s. 5. 
że koleżanki uważają przyjaźnienie się z chłopcami za powód do wstydu, nie wiadomo jednak, czy dotyczyło to szkoły polskiej, czy żydowskiej ${ }^{79}$.

Najbardziej uderza w relacjach czytelniczek (a czasem i czytelników) przekonanie, że równouprawnienie powinno być oczywiste, a miejsce kobiety jest nie tylko w domu. Dotyczyło to zarówno życia szkolnego, jak i przyszłości. „Mania mówi, że minęły czasy, kiedy zadaniem kobiety było pilnowanie ogniska domowego i wychowanie dzieci; dziś każda może iść dumnie w życie, świadoma swego znaczenia w społeczeństwie" "80.

W związku z tym jeden z chłopców zastanawiał się, czy „rycerskość dla kobiet" ma jeszcze w ogóle sens. Owszem, trzeba być grzecznym dla wszystkich, pomagać słabszym, ale źle potraktowany chłopiec wcale nie czuje mniejszej przykrości niż dziewczynka. Chłopcy, podobnie jak dziewczynki, bywają silni i słabi. Rycerskość jest pozostałością przeszłości, niedostosowaną do dzisiejszych czasów. Teraz dzieci uczą się razem, a kobiety pracują tak jak mężczyźni. Na przykład w jednej ze szkół zawsze chłopcy przestawiali ławki przed lekcją śpiewu, ale zastrajkowali, bo uznali, że dziewczynki też powinny to robić. Nauczycielka przyznała im rację. „Historyczna rycerskość chłopców została przez panią zniesiona”"1.

Co różniło zatem dziewczęta żydowskie, młode korespondentki „Małego Przeglądu”, od dziewcząt chrześcijańskich? Trudno odpowiedzieć na to pytanie, bo nie istnieje podobne badanie oparte na relacjach polskich dziewczynek. Jednak wydaje się, że jeden z elementów narracji może być charakterystyczny dla środowiska żydowskiego. Dotyczył on pracy zawodowej kobiet i aspiracji dziewcząt. Być może ambicje dziewcząt wynikały z tego, że korespondentki pochodziły przede wszystkim z akulturowanych - przynajmniej w części - rodzin, ale rodzin żydowskich. Żydowskie dziewczęta na co dzień spotykały się z pracą swoich matek, babć, sióstr. Praca kobiet jawiła się im zatem bardziej niż dziewczętom polskim jako coś naturalnego i oczywistego, a nie tylko konieczność.

Dlatego też korespondentki „Małego Przeglądu” bardzo zabiegały o zdobycie formalnego wykształcenia. Była to oznaka szybko postępującej modernizacji, nie zawsze dobrze widzianej przez starsze pokolenie. Jedna z nielicznych dorosłych korespondentek „Małego Przeglądu” przestrzegała przed nadmiernym przykładaniem wagi do wykształcenia, ale i ona była przekonana, że praca zawodowa jest oczywistością:

\footnotetext{
79 Zapytuja, ,„MP” (17 stycznia 1930), nr 17, s. 4.

${ }^{80}$ Z kraju. Brześć, „MP” (3 stycznia 1930), nr 3, s. 4.

${ }^{81}$ Rycerskość dla kobiet, „MP” (4 lutego 1927), nr 35, s. 8.
} 
Zastanawiam się nad listami dziewczynek. [...] Wszystkie szukają celu w życiu, upatrując go w nauce, w ukończeniu gimnazjum lub uniwersytetu. [...] Owszem, należy się kształcić, rozwijać umysł, ćwiczyć swoje władze, ale nie należy rozpaczać po ukończeniu szkoły powszechnej. Człowiek szczerze kochający wiedzę zdobędzie ją własnym sposobem czy w pracowni sukien, czy w warsztacie stolarskim. Często zdarza się, że jednostka szukająca odległego celu, wzdychająca do wzniosłych ideałów, zaniedbuje codzienne obowiązki, zapomina, że należy do rodziny i społeczeństwa, dla których pracować należy, by nie być darmozjadem ${ }^{82}$.

Niezależnie od oceny porady warto zauważyć, że jej autorka nie zwraca się do chłopców mających podobne jak dziewczynki aspiracje.

Tam, gdzie dziewczynki przedstawiały swoje plany czy marzenia na przyszłość, w większości przypadków widziały siebie jako osoby, które zrobiły karierę albo przynajmniej wykonują prestiżowy zawód. Na przykład: „Felicja pragnie zostać słynną tancerką i zdobywać laury w kraju i za granicą. - Hanka marzy o sławie i potędze. [...] - Frania pragnie uczyć rysunków. - Sala marzy, żeby zostać nauczycielką"83.

Marzenia dziewcząt dotyczące przyszłości, przedstawione w specjalnej rubryce „Dziewczynki marzą" ${ }^{44}$, też bywały ambitne. Jedna chciała być bogata i podróżować, inna także marzyła o podróżach, lecz niebezpiecznych - o spotkaniach z lwami i krokodylami. Ale są też bardziej konkretne wizje przyszłości. Helena chciała zostać prawniczką, adwokatką (w 1929 roku!); Sonia deklarowała: „Celem moim jest stać się pożyteczną dla ojczyzny obywatelką"85; Ala i Ewa zamierzały zostać nauczycielkami. Rok później w rubryce „Marzą - pragną” dziewczynki chciały: być prawnikiem, nauczycielką, dwie lekarkami, a „Felcia dąży do samodzielności, bo nie chce, żeby ktoś na nią pracował" "s6. Taką tendencję do wybierania prestiżowych zawodów zauważyły same czytelniczki: „W klasie naszej są dziewczynki, które gardzą wszystkiemi zawodami prócz nauczycielstwa. Przecież praca rąk jest tak samo ważna jak inne"87.

Tylko wyjątkowo pojawiały się opinie, że wprawdzie kobiety mają takie same prawa jak mężczyźni, ale dotyczy to wyłącznie młodych dziewcząt. Gdy mają rodzinę, ma być ona ważniejsza od kariery:

\footnotetext{
82 Wielunianka, Rada dla dziewcząt, „MP” (25 października 1929), nr 292, s. 4.

${ }^{83}$ Marza - pragna, „MP” (22 listopada 1929), nr 320, s. 3.

${ }^{84}$ Dziewczynki marza, „MP” (29 listopada 1929), nr 327, s. 1.

${ }^{85}$ Sonia, Biedne dzieci, „MP” (29 listopada 1929), nr 327, s. 1.

${ }^{86}$ Marza - pragna, „MP” (21 lutego 1930), nr 52, s. 4.

${ }^{87}$ Basia, Wybór zawodu - matura, „MP” (18 marca 1927), nr 78, s. 9.
} 
Jest już wiek XX, i ludzie rozumieją doniosłość tego. Rozumieją, że kobieta może tak samo pracować i zarabiać, jak mężczyzna, a jednak istnieje podział pracy. Jeżeli kobieta będzie zajęta pracą zarobkową, kto będzie dbał o mieszkanie, posiłki i dzieci? Rozumiem emancypację inaczej. Równouprawnione powinny być młode dziewczęta, na które nikt nie pracuje, od lat 14 do 18; powinny mieć takie same prawa do pracy, jak chłopcy ${ }^{88}$.

Rozgoryczenie wynikało stąd, że autorka parę razy starała się o pracę, którą wolano dać chłopcu. Należy jednak i tu podkreślić, że korespondentka uważała pracę kobiet za równie wartościową, co mężczyzn.

Na pewno różnicę widać wtedy, gdy mowa o religii i obrzędach religijnych. Trzeba bowiem pamiętać, że w judaizmie wyraźna była podrzędna rola kobiety. Być może właśnie dominująca w tej dziedzinie rola chłopców spowodowała, że część dziewczynek wyniosła z domu przeświadczenie, iż chłopcy są nawet nie tyle lepsi (bo to mogło dotyczyć także dziewcząt chrześcijańskich), co w pewnym sensie wybrani przez Boga: „Myślałam, że chłopcy - to coś świętego, ale jak zaczęłam z nimi rozmawiać i bawić się, dopiero zauważyłam, że są tacy sami ludzie, jak my, dziewczynki”"s9.

W społeczności wyznawców judaizmu dziewczęta były w pewien sposób wykluczone. Nie chodziły regularnie do synagogi, a gdy zaczęto je tam zabierać, początkowo były zafascynowane nie do końca znanymi im obyczajami. Na przykład: „Kiedy było Symchas Tore, byłam pierwszy raz w bóżnicy. Widziałam, jak ludzie tańczyli" ${ }^{90}$. Dziewczęta zwykle akceptowały fakt, że są z wielu obrzędów wykluczone, że są na drugim planie, nie mają podobnej uroczystości wprowadzenia w dorosłość jak ich bracia. Ale jednak czasem czuły, że są marginalizowane - szczególnie podczas Jom Kipur: „Smutny jest Sądny Dzień. Mamusia i tatuś idą do bóżnicy i w domu nie ma nikogo" $"$.

Jedyny ściśle religijny argument na rzecz bezdyskusyjnej niższości kobiet pojawił się w następującym liście chłopca:

Daremna jest obrona dziewcząt. [...] przecież mężczyzna co dzień z rana dziękuje Panu Bogu za różne rzeczy, a między innemi za to, że go nie stworzył kobietą. Gdyby kobieta równa była mężczyźnie, musiałaby dziękować, że nie stworzył jej

${ }^{88}$ Noemi, Dziewczynka, „MP” (14 stycznia 1930), nr 49 [prawdopodobnie pomyłka, powinno być: 14 lutego], s. 3.

${ }^{89}$ Mania z Pragi, W Otwocku, „MP” (17 maja 1929), nr 134, s. 8.

${ }^{90}$ Mania K., Wakacje i święta, „MP” (14 stycznia 1930), nr 49 [prawdopodobnie pomyłka, powinno być: 14 lutego], s. 4.

${ }^{91}$ Kajla, Wakacje i święta, „MP” (14 stycznia 1930), nr 49 [prawdopodobnie pomyłka, powinno być: 14 lutego], s. 4. 
mężczyzną. [...] Najmądrzejszy na świecie król Salomon powiedział [...]: „Jednego mężczyznę bez wad wśród tysiąca znalazłem - jednej kobiety wśród tysiąca nie znalazłem". Stąd wynika, że kobiety mają więcej wad niż mężczyźni. Talmud mówi, że kobiety są wolnomyślne, lubią dużo mówić, są ciekawe i leniwe ${ }^{92}$.

Fragment ten nie byłby tak interesujący - list bowiem powtarza tylko pewne argumenty religijnych Żydów - gdyby nie jego tytuł: „Zdanie biologa". A więc z religii miały wynikać prawdy czysto biologiczne.

Tylko sporadycznie pojawiały się informacje o życiu dziewczynek w tradycyjnych rodzinach i zazwyczaj nie budziły entuzjazmu. Jedna z korespondentek była oburzona, że zaręczono jej czternastoletnią koleżankę z klasy, łamiąc jej życie ${ }^{93}$. Nie widziała zatem w posiadaniu narzeczonego niczego romantycznego, zbyt wczesny związek traktowała jak tragedię. Nawet czytelniczki o bardziej konserwatywnych poglądach, na przykład potępiające aktualną modę i zbyt wyzywające ubrania, narzekały, że dziewczęta myślą o strojach, a nie o nauce, w związku z czym żadna w ich szkole nie zdobyła matury: „Maturzystki ubierają się modnie i zostają pannami na wydaniu. Znam dziewczynkę, która nie zdała matury, a jednak ubiera się według wszechświatowej mody, chodzi na tańce i bale, używa kosmetyków, i prawie z każdą tak jest" ${ }^{\prime 4}$.

Sporadycznie pojawiała się też (obecna także w „Naszym Przeglądzie”) wizja, że dyskryminacja dziewcząt i zagrożenia, z jakimi się spotykają, są podobne do sytuacji Żydów: „Położenie dziewcząt przypomina mi stan Żydów w średniowieczu, kiedy posługiwali się brzydkiemi metodami dla swojej obrony, a przecież nikt sprawiedliwy nie oskarży ich za to" ${ }^{\text {. }}$.

Pytanie, które należy zadać, brzmi: czy w przypadku dzieci istniała różnica między postrzeganiem siebie samych, swojej roli i problemów przez dziewczęta żydowskie i chrześcijańskie? Czy oprócz większej akceptacji pracy zawodowej kobiet są elementy charakterystyczne tylko dla dziewcząt żydowskich? Wydaje się, że w wypadku czytelniczek syjonistycznej prasy polskojęzycznej różnice między tymi grupami są niewielkie. Oczywiście dostrzegano antysemityzm, a co za tym idzie - część czytelniczek czuła się wyobcowana lub miała świadomość ograniczenia wyboru ról życiowych, ale dotyczyło to obu płci. Co więcej, wzorzec „żydowskiej dziewczynki” zainteresowanej przede wszystkim odbudową ojczyzny, odseparowanej od

92 Chłopcy o dziewczynkach, „MP” (19 października 1928), nr 288, s. 8.

${ }_{93}$ Pytania czytelników, „MP” (14 czerwca 1929), nr 162, s. 10.

${ }^{94}$ Fania, Pińsk, „MP” (20 stycznia 1928), nr 20, s. 8.

${ }_{95}$ Stefek, List Stefka - obrońcy dziewczynek..., s. 9. 
środowiska polskiego, zapatrzonej w żydowską tradycję, pobożnej - właściwie się w „Małym Przeglądzie” nie pojawiał. Owszem, dziewczęta pisały o Palestynie, ale nie był to dominujący w listach temat. Nawet listy z Erec nie przypominały w niczym podniosłych słów z „Dzienniczka” i „Chwilki” o radośnie wykonywanej przez wszystkich ciężkiej pracy fizycznej dla ojczyzny.

Oczywiście, zaskakująco daleko idące dążenie korespondentek „Małego Przeglądu" do emancypacji nie może być wyłączne wyjaśniane niedającymi się pogodzić rozbieżnościami w wymaganiach, z którymi musiały się zmierzyć żydowskie dziewczęta z syjonistycznych rodzin. Do pisma nadsyłały swoje prace dziewczynki odważniejsze, mniej bojące się krytyki, mające coś do powiedzenia. Prawdopodobnie w grę wchodził też - choć w mniejszym stopniu - dobór listów przez redakcję. Na pewno niespójność wzorców i propagowana przez syjonizm wspólna praca kobiet i mężczyzn w Palestynie, przy nadal obowiązującym konserwatywnym wychowywaniu dziewcząt, pozwoliła im na zauważanie dyskryminacji kobiet, a co więcej większych i absurdalnych wymagań stawianych dziewczynkom. Widać, że sprzeczności w wychowaniu dzieci moga prowadzić do samodzielnych decyzji wyboru tego najbardziej odpowiadającego im spośród proponowanych scenariuszy. Gdy nie można słuchać i naśladować, nie pozostaje nic innego, jak stworzyć i wybrać własną drogę. I taką drogę, jak się wydaje, często wybierały żydowskie czytelniczki.

\section{Bibliografia}

\section{1. Źródła opublikowane}

Awakening Lives: Autobiographies of Jewish Youth in Poland before the Holocaust, red. Jeffrey Shandler, New Haven-London 2002.

„Chwilka” 1925-1930.

„Dzienniczek dla Dzieci i Młodzieży” 1925-1930.

„Mały Przegląd” 1926-1930.

Ostatnie pokolenie. Autobiografie polskiej młodzieży żydowskiej okresu międzywojennego ze zbiorów YIVO Institute for Jewish Research w Nowym Jorku, red., wstęp i przypisy Alina Cała, Warszawa 2003.

\section{Opracowania}

Antosik-Piela Maria, Tożsamość i ideologia. Literatura polsko-żydowska wobec syjonizmu, Kraków 2020.

Bar-El Adina, Jewish Children's Periodicals in Poland between the Two World Wars - in Three Languages, „Rocznik Historii Prasy Polskiej” 16 (2013), nr 1. 
Cała Alina, Kobiety wobec tradycyjnych norm życia rodzinnego w społecznościach $\dot{z} y d o w s k i c h w$ Polsce międzywojennej, [w:] Kobieta i kultura życia codziennego, wiek XIX i XX, red. Andrzej Szwarc, Anna Żarnowska, Warszawa 1997.

Karczewska Agnieszka, Polsko-żydowska republika marzeń. O „Chwilce dla Dzieci i Młodzieży” (1925-1937), Lublin 2015.

Kijek Kamil, Dzieci modernizmu. Świadomość, kultura i socjalizacja polityczna młodzieży żdowskiej w II Rzeczypospolitej, Wrocław 2017.

Landau-Czajka Anna, Not Just „Mały Przeglą”: The Ideals and Educational Values Expressed in Jewish Polish-Language Journals for Children and Young Adults, [w:] New Directions in the History of the Jews in the Polish Lands, red. Antony Polonsky, Hanna Węgrzynek, Andrzej Żbikowski, Boston 2018.

Landau-Czajka Anna, Wielki „Mały Przegląd”. Społeczeństwo i życie codzienne w II Rzeczypospolitej w oczach korespondentów „Małego Przeglądu”, Warszawa 2018. Mickute Jolanta, Making of the Zionist Woman: Zionist Discourse on the Jewish Woman's Body and Selfhood in Interwar Poland, East European Politics and Societies, http://eep.sagepub.com/content/28/1/137 [dostęp: 2 lipca 2021]. Papuzińska Joanna, Prasa dziecięca okresu międzywojennego a „Mały Przegląd”, [w:] O „Małym Przegladzie” po latach. Materiaty ze spotkania korespondentów i czytelników, red. Anna Wernik, Warszawa 1989.

Anna Landau-Czajka IH PAN amverdana@gmail.com 